\title{
PELAYANAN PUBLIK DALAM KONTEKS PEMENUHAN KEBUTUHAN DASAR MASYARAKAT
}

\author{
Agus Rianto \\ Dosen Universitas Muhammadiyah Cirebon \\ Email:agusrian1976@gmail.com
}

\begin{abstract}
ABSTRAK
Pelayanan masyarakat dapat dikatagorikan efektif apabila masyarakat mendapatkan kemudahan pelayanan dengan prosedur yang singkat, cepat, tepat dan memuaskan. Paling sering dikeluhkan warga Desa Klangenan adalah jaminan tepat waktu dalam proses pelayanan seperti pembuatan E-KTP dan lain-lain. Penelitian ini bertujuan untuk mengetahui Citra Pelayanan Publik di Desa Klangenan Kecamatan Klangenan Kebupaten Cirebon.
\end{abstract}

Kata Kunci: Citra, Layanan Publik, E-KTP

\section{ABSTRACT}

The service image is said to be important because it is the overall impression that is formed in the minds of the public about the public services provided by the village apparatus. Community service can be categorized effectively if the community gets the ease of service with a short, fast, appropriate and satisfying procedure. Most often complained by residents of Klangenan Village is a guarantee of timely service processes such as making E-KTP and others. This study aims to determine the Public Service Image in Klangenan Village, Klangenan District, Cirebon Regency.

Keywords: Image, Public Service, E-KTP 


\section{PENDAHULUAN}

Pelayanan publik merupakan pelayanan dasar dalam penyelenggaraan pemerintahan. Pelayanan publik sebagai indikator penting dalam penilaian kinerja pemerintah, baik ditingkat pusat maupun daerah. Penyelenggaraan pemerintahan dikatakan baik jika pelayanan publik yang dilakukan berorientasi pada kepentingan masyarakat. Pelayanan yang baik dan berkualitas memberikan implikasi kepuasan kepada masyarakat, karena masyarakat secara langsung menilai terhadap kinerja pelayanan yang diberikan. Indicator kepuasan masyarakat itulah yang menjadi tolok ukur keberhasilan penyelenggara pemerintahan.

Undang-Undang Nomor 25 Tahun 2009 tentang Pelayanan Publik dalam Pasal 1 ayat (1) bahwa pelayanan publik adalah kegiatan dalam rangka pemenuhan kebutuhan pelayanan sesuai dengan peraturan perundang-undangan bagi setiap warga negara dan penduduk atas barang, jasa dan/atau pelayanan administratif yang disediakan oleh penyelenggara pelayanan publik. Dipertegas pula dalam ayat (7), bahwa standar pelayanan adalah tolok ukur yang dipergunakan sebagai pedoman penyelenggaraan pelayanan dan acuan penilaian kualitas pelayanan sebagai kewajiban dan janji penyelenggara kepada masyarakat dalam rangka pelayanan yang berkualitas, cepat, mudah, terjangkau, dan terukur.

Hakekat pelayanan publik dengan memberikan pelayanan prima kepada masyarakat merupakan tugas utama yang hakiki dari sosok aparatur, sebagai abdi Negara dan abdi masyarakat. Pelayanan publik yang berkualitas atau yang biasa disebut dengan pelayanan prima merupakan pelayanan terbaik yang memenuhi standar kualitas pelayanan. Pelayanan publik adalah segala kegiatan pelayanan yang dilaksanakan oleh penyelenggara pelayanan publik sebagai upaya pemenuhan kebutuhan penerima pelayanan, maupun dalam rangka pelaksanaan ketentuan peraturan perundang-undangan.

Penyelenggaraan pelayanan publik adalah petugas pelayanan publik baik pemerintah daerah maupun Badan Usaha Milik Daerah yang menyelenggarakan pelayanan publik. Sedangkan penerima layanan publik adalah perseorangan atau kelompok masyarakat dan badan hukum yang memiliki hak dan kewajiban terhadap suatu pelayanan publik.

Citra pelayanan dikatakan penting karena merupakan keseluruhan kesan 
yang terbentuk dibenak masyarakat tentang pelayanan publik yang diberikan oleh aparatur desa. Biasanya citra menyangkut karakteristik suatu pelayanan yang nantinya akan membentuk citra dalam persepsi masyarakat. Citra yang dibangun berdasarkan pada manfaat yang dibutuhkan dan diinginkan oleh khalayak.

Untuk mengetahui pandangan masyarakat terhadap sejauh mana pelayanan publik dalam pembuatan EKTP yang telah diberikan dan bagaimana tingkat kepuasan masyarakat Desa Klangenan Kecamatan Klangenan Kabupaten Cirebon mengenai pelayanan publik. Maka penulis mengambil judul dalam Tugas Akhir ini adalah "Citra layanan Publik dalam Pembuatan E-KTP di Desa Klangenan Kecamatan Klangenan Kabupaten Cirebon”.

\section{LANDASAN TEORETIS}

Menurut Kamus Besar Bahasa Indonesia (1990:667), citra adalah pemahaman kesan yang timbul karena pemahaman akan suatu kenyataan. Sedangkan menurut Linggar dalam Teori dan Profesi Kehumasan serta Aplikasinya (2000:69) mendefinisikan citra sebagai kesan yang benar, yakni sepenuhnya berdasarkan pengalaman, pengetahuan serta pemahaman atas kenyataan yang sesungguhnya.

Citra (image) adalah seperangkat keyakinan, ide dan kesan yang dimiliki oleh seseorang terhadap suatu objek (Kotler dalam Sutisna, 2001:33). Menurut Kotler (2002:97) secara lebih luas mendefinisikan tentang citra sebagai jumlah dari keyakinan, gambaran, dan kesan yang dipunyai seseorang pada suatu objek. Objek yang dimaksud bisa berupa orang, organisasi, kelompok orang atau yang lainnya yang dia ketahui.

Sedangkan pelayanan, berkaitan erat dengan masyarakat, sehingga pelayanan lebih dikenal dengan istilah pelayanan publik. Publik bersal dari bahasa inggris public yang berarti masyarakat umum dan negara, kata publik dalam bahasa Indonesia diartikan sebagai umum orang banyak dan ramai. Pelayanan publik menurut Sinambela (2006:5) adalah pemenuhan keinginan dan kebutuhan masyarakat oleh penyelenggara negara.

Pelayanan publik adalah segala kegiatan dalam rangka pemenuhan kebutuhan dasar sesuai dengan hak-hak dasar setiap warga negara dan penduduk atas suatu barang, jasa dan atau pelayanan administrasi yang disediakan 
oleh penyelengggara pelayanan yang terkait dengan kepentingan publik.

\section{METODOLOGI PENELITIAN}

Penelitian ini menggunakan metode deskriptif pendekatan kualitatif. Penelitian ini mendeskripsikan data yang diperoleh dari hasil penelitian mengenai Citra Pelayanan Publik di Desa Klangenan Kecamatan Klangenan Kabupaten Cirebon dalam pembuatan EKTP. Data dihimpun dengan pengamatan seksama, mencakup deskripsi dalam konteks yang mendetail catatan-catatan hasil wawancara yang mendalam, serta hasil analisis dokumen dan catatan.

Teknik pengumpulan data merupakan salah satu hal yang penting bagi sebuah penelitian, sehingga data yang diperoleh benar-benar sesuai dengan judul yang telah ditentukan sebelumnya.

Dalam penelitian ini pengumpulan data dilakukan dengan menggunakan beberapa teknik, yaitu sebagai berikut:

1. Observasi, yaitu teknik pengumpulan data yang digunakan dalam penelitian untuk melakukan pengamatan secara langsung di lapangan. Teknik ini digunakan untuk mengamati pelaksanaan pelayanan publik yang terjadi antara pegawai dan masyarakat sebagai pengguna layanan di kantor desa Klangenan. Dalam penelitian ini dilakukan pengamatan lapangan dalam pelaksanaan pelayanan publik.

2. Wawancara, yaitu memperoleh data atau informasi secara mendalam mengenai pelaksanaan pelayanan publik di Desa Klangenan yang dilakukan oleh pegawai dan masyarakat. Teknik wawancara ini dilakukan dengan menyiapkan pedoman wawancara yang berisi sejumlah pertanyaan dan pernyataan yang memuat pokok-pokok permasalahan yang akan diteliti.

3. Dokumentasi, yaitu teknik pengumpulan data dengan menghimpun dan menganalisis dokumen-dokumen yang mendukung peneltian.

\section{PEMBAHASAN}

Kartu Tanda Penduduk (KTP) adalah identitas resmi penduduk sebagai bukti diri yang diterbitkan oleh instansi pelaksana yang berlaku di seluruh wilayah Negara Kesatuan Republik Indonesia. Penduduk hanya diperbolehkan memiliki 1 (satu) KTP yang tercantum Nomor Induk Kependudukan (NIK). NIK merupakan 
identitas tungggal setiap penduduk dan berlaku seumur hidup.

Pelayanan di Desa Klangenan mempunyai standar pelayanan karena di Desa Klangenan memiliki SOP (Standar Operasional Prosedur) dengan memperhatikan tempat pelayanan, biaya pelayanan, keyamanan pengguna dalam melakukan pelayanan. Di Desa Klangenan sendiri menggunakan loket satu pintu agar pengguna layanan tidak tercecer berkumpul di loket tersebut.

Berikut prosedur pelayanan pembuaatan KTP di desa Klangenan:

a. Pemohon datang ke tempat pelayanan membawa surat panggilan

b. Pemohon menungggu pemanggilan nomor antrian

c. Pemohon menuju keloket

d. Petugas melakukan verifikasi data penduduk dengan basis data

e. Petugas mengambil foto pemohon secara langsung

f. Pemohon membubuhkan tanda tangan pada alat perekam tanda tangan

g. Selanjutnya dilakukan perekaman sidik jari dan pemindaian retina mata

h. Petugas membubuhkan tanda tangan dan stempel pada surat panggilan sekaligus sebagai bukti bahwa penduduk telah melakukan perekaman foto, tanda tangan dan sidik jari.

Undang-undang No.6 Tahun 2014 tentang Desa mengamanatkan dikembangnya sistem informasi desa (pasal 86 UU Desa) untuk mendukung proses pembangunan desa. Dengan sistem informasi yang memadai (perangkat lunak, perangkat keras, jaringan dan sumber daya manusia) diharapkan desa mampu memetakan potensi desa dan membuat perencanaan pembangunan yang tepat, efektif, dan efisien.

Pelayanan di Desa Klangenan Kecamatan Klangenan Kabupaten Cirebon sekarang sudah cukup mudah dilakukan karena sekarang pelayanan desa dibantu dengan adanya SIDESI (Sistem Informasi Desa Konservasi). SIDESI merupakan program yang didalamnya terdapat strategi, kegiatan, dan indikator yang dapat digunakan untuk mendukung pembangunan desa sejahtera dan lestari.

Namun walaupun pelayanan sudah mudah dilakukan tetap terjadi adanya kendala dalam proses implementasi pelayanan e-KTP yang sampai saat ini 
masih dijumpai beberapa kendala.

Kendala yang dihadapi dalam pembuatan e-KTP di Desa Klangenan adalah:

a. Terdapat kesalahan data penduduk. Pada proses perekaman data e-KTP, operator akan mengkonfirmasi kepada penduduk bersangkutan apakah datanya sudah benar atau belum dan selanjutnya proses perekaman dilanjutkan. Namun karena banyaknya jumlah penduduk yang dihadapi dengan kapasitas operator dan proses perekaman hingga larut malam, kelelahan operator terkadang menimbulkan keliruan data yang diinput.

b. Aktivasi e-KTP. Untuk e-KTP yang sudah tercetak perlu di aktivasi apakah data yang tercantum sudah benar atau tidak. Namun beberapa penduduk atau petugas pemerintah hanya sebatas mendistribusikan eKTP saja dan aktivasi dilakukan dikemudian hari. Sehingga menyebabkan penduduk yang memiliki jarak yang cukup jauh dari kantor pemerintahan bersangkutan enggan melakukan aktivasi. Komputer eror atau peralatan macet. Seringkali masalah seperti ini terjadi dikarenakan kurangnya perawatan dalam menjaga peralatan di Desa
Klangenan ini, dan juga masih menggunakan peralatan yang masih kurang canggih dalam proses layanannya.

Pemadaman listrik oleh PLN sangat mengganggu pengerjaan e-KTP di desa Klangenan. Dengan demikian adanya pemadaman listrik maka alat untuk memproses pembuatan e-KTP tidak dapat berjalan karena peralatan menggunakan listrik seperti halnya komputer, alat pencetak berkas, dan lain-lain.

Ketepatan waktu penyelesaian pelayana merupakan salah satu faktor dalam upaya mewujudkan kepuasan masyarakat. Masyarakat mengharapkan penyelesaian pelayanan dengan cepat dan tepat waktu. Waktu penyelesaian adalah waktu yang ditetapkan sejak pengajuan permohonan/pendaftaran sampai dengan penyelesaian pelayanan termasuk pengaduan. Desa Klangenan Kecamatan Klangenan Kabupaten Cirebon memiliki SOP (Standar OPerasional Prosedur) dalam upaya memberikan pelayanan yang baik dan menimbulan kesan/citra yang baik terhadap Desa Klangenan.

Seperti yang dikatakan Bapak Rochmat Hidayat selaku Kuwu Desa Klangenan: "Ada hal yang harus disamakan persepsinya terkait dengan 
administrasi kependudukan itu ada dokumen yang tidak dicetak di desa yang sekarang lagi sama-sama kita maklum ada persoalan KTP, Kartu Keluarga, dan Akte tiga-tiganya dicetak diskucapil blangko nya dari pusat prosedurnya disana dan kita hanya membuat, nah masyarakat taunya bahwa administrasi diurus oleh kita sehingga sampai hari ini blangko yang kosong sampai orang bikin KTP berbulan-bulan belum jadi itu ada persepsi pubik kepada desa ini harus diluruskan".

Berdasarkan pernyataan responden diatas bahwa ada kesalahpahaman antara desa dan masyarakat adanya kurang komunikasi didalam pelayanan, ketidaktahuan masyarakat atas blangko yang kosong menjadi faktor masyarakat menyalahkan pelayanan di desa sedangkan Desa Klangenan sudah melayani sesuai standar dan semaksimal mungkin. Persepsi masyarakat mengenai kepastian waktu penyelesaian dapat disimpulakan bahwa kepastian waktu sudah sesuai jadwal pelayanan yang ada, akan tetapi tegantung dari penyelesaian di kecamatan, untuk lamanya penyelesaian tergantung adanya masalah yang terjadi dalam proses pembuatan e-KTP.

Ketersediaan sumber daya manusia yang berkualitas sangat berpengaruh terhadap hasil pelayanan yang memuaskan. Penyelenggaraan pelayanan publik di Desa Klagenan Kecamatan Klangenan Kabupaten Cirebon harus memenuhi kesopanan, dan keramahan.

Perilaku pegawai merupakan hal yang sangat diperhatikan oleh pengguna layanan terutama dalam pengurusan surat-surat dimana masyarakat pengguna layanan berhadapan langsung dengan pegawai pada bagian ini.

Berdasarkan keterangan dari Bapak Rochmat Hidayat selaku Kuwu Desa Klangenan mengatakan:

"Iya tentu saja kita harus ramah dan sopan dalam melayani masyarakat apapun keluhannya kita layani dengan sebaik mungkin tidak membeda-bedakan. karena itu mencerminkan juga pelayanan kita itu baik".

Ketika melakukan wawancara dengan warga RT/01 RW/03 Ny. Engkus Agustina mengungkapkan:

"Pegawai Desa Klangenan itu ramah-ramah dan sopan apalagi bapak kuwunya yang selalu menggunakan bebasan jika bertemu warga namun ada satu atau dua orang yang agak judes dalam melayani mungkin karena beliau sangat sibuk".

Berdasarkan pernyataan responden di atas dapat diartikan bahwa persepsi masyarakat terhadap perilaku pegawai di 
Desa Klangenan Kecamatan Klangenan Kabupaten Cirebon mengenai keramahan dan kesopanan secara keseluruhan menyatakan ramah dan sopan, walaupun ada dari beberapa oknum pegawai yang kurang bersikap ramah. Hal tersebut dikarenakan kemunkinan pegawai sedang sibuk.

\section{SIMPULAN}

Pelayanan Desa Klangenan sudah menjalankan sesuai Undang-Undang Nomor 25 Tahun 2009 tentang Pelayanan Publik, Desa Klangenan juga melakukan pelayanan berdasarkan SOP (Standar Operasional Prosedur) meskipun ada beberapa kendala dala proses pelayanannya menyangkut sarana dan kesalahan teknis namun semuanya masih bisa berjalan dengan baik.

Dalam pelaksanaan pelayanan pembuatan e-KTP di Desa Klangenan Kecamatan Klangenan Kabupaten Cirebon masih terdapat beberapa faktor penghambat dalam pelayanan seperti halnya komunikasi dan juga keterbukaan yang kurang dilakukanoleh pihak desa. Dari keseluruhan data dan persepsi masyarakat bisa kita simpulkan bahwa citra pelayanan publik dalam pembuatan e-KTP di Desa Klangenan Kecamatan
Klangenan Kabupaten Cirebon masuk pada kategori citra baik karena hampir dari masyarakat desa klangenan memberi kesan yang cukup baik terhadap pelayanan di Desa Klangenan.

\section{DAFTAR PUSTAKA}

Kotler, Philip. Terj. Ancelta Aniwati Hermawan, S.E., MBA (1995). Manajemen Pemasaran: Analisis, Perencanaan, Implementasi, dan Pengendalian. Jakarta: Salemba Empat

Kamus Besar Bahasa Indonesia, Jakarta: Balai Pustaka. 1990

Sinambela, Lijan Poltak. 2006. Reformasi Pelayanan Publik: Teori, Kebijakan, dan Implementasi. Jakarta: PT Bumi Aksara. 